\title{
Effectiveness of Social Media in Monitoring Cadets Performance on Shipboard Training in Selected Maritime Schools Using System Quality Metrics
}

\author{
FROILAN D. MOBO, FRIEDR
}

Philippine Merchant Marine Academy, Pmma Complex, San Narciso, Zambales.

\begin{abstract}
The Shipboard Training in the selected Maritime Institution uses a distributed documentation partially manual process in monitoring the performance of the cadets that most likely causes the delay and inconsistency of reports. Their Department uses any Social Media Website in assessing/validating the reports on the performance of the cadets. The Department of Shipboard Training receives a summary of the report through Social Media Website. Technology nowadays is overwhelming that resulted to change faster from a stand-alone system to a web based technology which is capable of supporting almost all of the computerized transactions using an open source mobile applet and Content Management Systems. Most of the organizations have embraced technology and have developed exceptional online programs that provide easy access and massive communication. These maritime schools entirely take after the IMO model courses as proclaimed by the 1978 tradition on Standards of Training, Certification and Watch keeping for seafarers (STCW), as altered in 1995 , and are the main ones permitted by our legislature to lead and regulate baccalaureate courses with 3-year scholastics in addition to 1 year managed shipboard apprenticeship for deck and engine cadets.
\end{abstract}

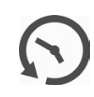

Article History

Received: 10 May 2018 Accepted: 24 May 2018

\section{Keywords}

Cadette performance, Shipboard training , Maritime schools, System quality metrics.

\section{Introduction}

The Shipboard Training in the selected Maritime Institution uses a distributed documentation partially manual process in monitoring the performance of the cadets that most likely causes the delay and inconsistency of reports. Their Department uses Cloud Based Application Performance Monitoring System in assessing/validating the reports on the performance of the cadets. The Shipboard Training receives a summary of the report through Social Media Website which most often received after the cadets have finished their training, coming from the different shipping companies and will be assessed in the said application. Each performance of the cadets is automatically recorded in Cloud Based Application Performance Monitoring System. In fact the result of performance of the cadets should be received during the training. Also, one of the major

CONTACT Froilan D. Mobo froilanmobo@gmail.com Philippine Merchant Marine Academy, Pmma Complex, San Narciso, Zambales.

(C) 2018 The Author(s). Published by Techno Research Publishers

This is an 6 Open Access article licensed under a Creative Commons Attribution-NonCommercial-ShareAlike 4.0 International License (https://creativecommons.org/licenses/by-nc-sa/4.0/ ), which permits unrestricted NonCommercial use, distribution, and reproduction in any medium, provided the original work is properly cited.

To link to this article: http://dx.doi.org/10.13005/ojcst11.02.05 
reasons why there is a need to used a monitoring system is that, the Commission on Higher Education (CHED), Maritime Industry Authority (MARINA) and Norwegian Ship owners Association (NSA), needs a real time report system $6,7,8,9,10$.

Technology nowadays is overwhelming that resulted to change faster from a stand-alone system to a web based technology which is capable of supporting almost all of the computerized transactions using Social Media Website. Most of the organizations have embraced technology and have developed exceptional online programs that provide easy access and massive communication. These maritime schools entirely take after the IMO model courses as proclaimed by the 1978 tradition on Standards of Training, Certification and Watch keeping for seafarers (STCW), as altered in 1995, and are the main ones permitted by our legislature to lead and regulate baccalaureate courses with 3-year scholastics in addition to 1 year managed shipboard apprenticeship for deck and motor cadets. The Commission on Higher Education (CHED) perceived and licensed these sea courses offered by appropriately approved scholarly establishments. On November 12, 1999, the CHED discharged the names of sea schools it considered to have passed the IMO-STCW benchmarks. This raised another contention on how CHED concocted their assessment convention. Beside true blue sea schools, there are sea preparing focuses that ought to be licensed by the Maritime Training Council (MTC). Both CHED and MTC screen the instructive environment without bounds world-class Filipino seafarers ${ }^{1,2,3,4}$.

\section{Statement of the Problem}

The study focused in obtaining the effectiveness of the social media in performance monitoring system of the $2^{\text {nd }}$ class midshipmen cadets in selected maritime institution in Region III using Social Media.

Specifically, the study sought to find answers to the following questions:

- What is the profile of the respondents when group according to:
a. age;
b. sex;
c. course; and
d. occupation?

- What are the respondents' perceptions on the levels of effectiveness of the social media with regards to the following parameters:

a. accuracy;

b. security;

c. user friendliness; and

d. functionality?

- Is there a significant difference among the parameters across profile variables?

- Is there a significant relationship among the parameters of the level of effectiveness of the social media?

Table 1 shows the regression analysis of the relations. If can be seen from the table that $5=0.31$ which imlies a low positive relationship between profile and system quality metrics, also $31 \%$ of the profile had an effect to the SQM while $10 \%$ of the SQM re being affected or explained by the profile variables. Since $F=3.66$, sig $=0.05$, there is a significant relationship between the profile and SQM. This implies that profile variables has an effect to the System Quality Metric.

Table 1: Significant Relationship among the Parameters of the Level of Effectiveness of the Social Model

\begin{tabular}{lllllll}
\hline $\begin{array}{l}\text { Significant Relationship among } \\
\text { the parameters of the Level of } \\
\text { Effectiveness of the Social Model }\end{array}$ & $\mathbf{R}$ & $\mathbf{R}$ square & $\mathbf{F}$ & Sig. & Remarks \\
\hline 1 & 0.31 & 0.10 & 3.66 & 0.00 & Significant \\
\hline
\end{tabular}




\section{Salient Findings}

The group according to school were compose of 63 or percentage of 36.4 cadets from Maritime School X; then PMMA with a frequency of 58 and percentage of 33.5 cadets ; lastly Maritime School $X$ with frequency of 52 and percentage of 30.1 cadets in evaluating the effectiveness of social media in monitoring cadet's performance on shipboard.

There is a significant difference on the perception among the parameters on the levels of effectiveness of social media.

\section{Conclusions}

From the findings, the following conclusions which are binding on the respondents are arrived at:

- That most of the respondents are from Maritime School $X$ with a frequency of 63 and percentage of 36.4 ; then PMMA with a frequency of 58 and percentage of 33.5 ; lastly Maritime School $Y$ with frequency of 52 and percentage of 30.1. This implies that majority of the respondents came from Maritime School X, and according to the initial survey of the researcher, Maritime School $X$ have more enrollees than the other two schools.

- Based on the results of the study, using Social Media on respondents' perception on the levels of effectiveness of the social media with regards to the following parameters perceives very effective.

- That there is a difference on the perception of the respondents on System Quality Metrics when grouped according to the parameters across profile variables.

- $\quad$ That there a significant relationship among the parameters of the level of effectiveness of the social media between profile variables that has an effect to the System Quality Metrics.

\section{Recommendations}

In view of the findings and conclusions, the researcher would like to recommend the following:

- Social Media should be used at the Department of Shipboard Training to monitor the performance of the cadets while on boardship training in selected maritime schools in Region III.

- The implementation of the Social Media for the Cadets in Selected Maritime Schools in Region III. It is expected that with continuous maintenance to ensure smooth operation.

- DST Staff should be aware and orient the cadets on how to use Social Media moderately. Monitor performance diligently and encourage cadets to indulge to a more fulfilling and productive activities. Social Media can be an aid on shipboard training activities.Social Media involved nowadays and nothing can keep them away to that, College officials can incorporate Social Media Technology in their curriculum. The College can facilitate the revision of their curriculum to adapt to the changing needs of the classroom activities. Social Media offers a wide range of opportunity to the students of the said department. the proper way of using Social Media and to practice what they have learned by developing applications that can be used in the Social Media.

- $\quad$ Research undertaking must be done to further improve its features and capabilities.

\section{Acknowledgment}

I would like to express my sincere heartfelt and deepest gratitude to those who have rendered their time, knowledge, guidance and support to make this work a reality.

Dr. Elizabeth A. Montero, the University President and Chairman of the Examination Committee, for giving encouragement to the research in pursuing this study.

Dr. Pedro Q. Pascua, Graduate Coordinator and his Dissertation adviser for being approachable and for extending his scholarly advices and guidance.

Dr. Zandra Z. Paruginog and Dr. Alfredo F. Aquino, Members of the panel for their encouragement and sincere comments.

Dr. Helen F. Dupale, OIC-Dean of the Graduate School who was very accommodating and supportive, and for sharing her expertise for the improvement of the study.

Former Vice Gov. Ramon G. Lacbain II, HON. Gov. Hermogenes E. Ebdane JR., Hon. Mayor Jefferson 
Khonghun, Hon. Congressman Jeffrey Khonghun, Director Hon. Anne Marie C Gordon and Hon. Congresswoman Cherryl Deloso Montalla for approving and giving their financial assistance in pursuing this study.

C/E Charlie M. Pandongan, MSc, Dean, College of Marine Engineering of the Philippine Merchant Marine Academy and LCDR Marcos C TAberdo PMMA, Dean, College of Marine Transportation for their consideration, understanding and support in the conduct of this study.

My friends Rev. Father Willie M. Monsalud, Rev. Father Ferdinand Fajardo and Rev. Father Dexter
Fabie in giving their spiritual advice and guidance in this study.

To his loving and supportive family and lovable honey, for their prayers, support and encouraging words.

To all his friends at Philippine Merchant Marine Academy, PMMA's $1^{\text {st }}$ Class Midshipmen Batch 2016, who had assisted in distributing the questionnaires.

And above all, to GOD ALMIGHTY, for showering me all the love, guidance and blessings.

\section{References}

1. Auxier, Brooke Elizabeth (2012) Social Media Instruction in Journalism, and Mass Communications Higher Education, Unpublished Thesis, Maryland

2. Beltran-Cruz, Maribel and Cruz, Shannen Belle (2013). The Use of Internet-Based Social Media as a Tool in Enhancing Student's Learning Experiences in Biological Science, Published Dissertation, New Era University, Quezon City

3. Bermudez, Noel A. (2012) Effects of Social Media on Individual Voting, Unpublished Thesis, Gonzaga University,

4. Cancio, J. M. (2009) An exploratory study on the social media marketing phenomenon in the Philippines, Unpublished Thesis, University of the Philippines, Quezon City.

5. Fernando, K.A., \& Reyes, C (2013) A Comparative Study on the Social Media Usage of Gawad Kalinga and Unilever for the Promotion of Their Services and Products, Unpublished Thesis, University of the Philippines, Quezon City.
6. Gonzales, Reginald H (2014). Social Media as a Channel and its Implications on Cyber Bullying, Published Dissertation, Lyceum of the Philippines University, Cavite.

7. Nikolova, Svetoslava Nikolova (2012) The effectiveness of social media in the formation of positive brand attitude for the different users, Unpublished Thesis, Amsterdam.

8. Pate, Alay Rameshbhai Comparative (2011) Study and Analysis of Social Media, Unpublished Dissertation, San Diego State University,California.

9. Perdue, David Joshua (2016) Social Media Marketing: Gaining a Competitive Advantage by Reaching the Masses, Unpublished Dissertation, Liberty University.

10. Tamayo, Josan D. and dela Cruz, Giselle Sacha G (2014) The Relationship of Social Media with the Academic Performance of Bachelor of Science in Information Technology Students of Centro Escolar University Malolos, Published Thesis, Malolos, Bulacan. 